\title{
Influence of the Correct Management of the IT Department on the Quality of Data And Information Processing
}

\author{
Edita Šilerová ${ }^{1}$, Klára Hennyeyová ${ }^{2}$, Robert Michálek $^{1}$, Eva Kánská ${ }^{1}$, Jan Jarolímek ${ }^{1}$ \\ ${ }^{1}$ Faculty of Economics and Management, Czech University of Life Sciences in Prague, Czech Republic \\ ${ }^{2}$ Faculty of Economics and Management, Slovak University of Agriculture Nitra, Slovak Republic
}

\begin{abstract}
The article examines the influence of the existence of an information system and the existence of an information strategy for the management of information systems and information and communication technologies in the company. Two hypotheses have been identified: H1 - in the monitored sample of enterprises there is an increasing tendency of the existing department of informatics, as a separate unit and $\mathrm{H} 2$ - monitored respondents are used to manage information systems and information and communication technologies created information strategy. The article was developed based on scientific methods - using holistic methodology, analysis, synthesis, induction and deduction. The established hypotheses were verified by a questionnaire survey. The questionnaire survey was supplemented by direct questioning. The established hypotheses were not confirmed.
\end{abstract}

\section{Keywords}

Information systems, information and communication technologies, informatics management, information strategy.

Šilerová, E., Hennyeyová, K., Michálek, R., Kánská, E. and Jarolímek, J. (2017) "Influence of the Correct Management of the IT Department on the Quality of Data And Information Processing", AGRIS on-line Papers in Economics and Informatics, Vol. 9, No. 4, pp. 91-98. ISSN 1804-1930. DOI 10.7160/aol.2017.090409.

\section{Introduction}

Managing large corporations and corporations is not a simple matter today. In fact, it could be said that despite all the technical advances, it is now more difficult than ever before. Often, medium and small businesses face complex situations and regularly face complicated tasks.

Success or failure in business is becoming more and more relevant today. Who can properly use available information has a strategic advantage over others who cannot, or do not have the right information available at the right time. The quality of the entire control process is therefore fully dependent on the way and the ability to extract information and work with it. There are many ways to get information from corporate data sources. As information and communication technologies develop as quickly as possible, approaches to obtaining information on the state of the matter - the economic situation of the company, market situation, production and others according to the specific requirements of the management - are also being developed. Information has gradually become a highly desirable commodity and, in addition to land, labor and capital, is becoming one of the most important business resources.

Knowledge management begins with the identification of sources of information and reusable knowledge that are valuable to meeting the organization's strategic goals. Sources of data, information and knowledge can be found inside and outside organizations. Data, information, knowledge that arises and exist within organizations is relatively easy to access. Data and information are, in most cases, stored in databases of information systems and are available (based on access rights) to authorized users. The external environment provides data and information through media companies (unsorted information, targeted information, via websites, through paid surveys). Relatively easier, businesses get internal information, that is, information from the internal environment. External information and business information is gained less easily. The quality and way of obtaining internal information is fully dependent on the enterprise information system. Business information system 
should be fully integrated and should respect the business processes of different functional areas. Therefore, the business information system cannot be created without a clearly defined global and information strategy. The design of the information system must also fully respect partial strategic concepts in the company. Any other approach is very risky. If there is no compliance with the above-mentioned procedure, i.e. the introduction of an information system without information strategy, there are many problems that arise with regularity in all companies (Tchoffa et al., 2013).

The quality of information systems also affects the possibility and ability of the organization's employees to obtain data and information, respectively knowledge from various informal sources. The next step in working with information and knowledge in the organization is to create a plan to use identified sources of information and knowledge and to create a definition of the environment where knowledge will be applied. It is equally clear to define what activities the knowledge will be used for. Knowledge is created continuously and sporadically in the organization's information system. Continuous feedback takes place in the knowledge used, thus enriching knowledge with further experience and gaining new added value. Knowledge in most cases is owned by its owner, i.e. the creator of knowledge - e.g. a company employee. Employees also use their capabilities and abilities, and provide the employees who use them based on the communication model for other activities in the organization - decision-making, new processes, and the use of new technologies.

Information and knowledge have gradually become the necessary business resources that influence business management. The way of their creation and acquisition is fully independent of the way of communication in individual companies. At present, information management and especially knowledge is not addressed in most businesses. Accuracy and up-to-date information is crucial for each organization to further develop, increase competitiveness, improve market position, increase image and improve goodwill. It is not just a static data analysis (mostly historical data), but more and more about data processing in real time. Data and information stored in information systems create support mainly for production, economy, business processes, to optimize processes in a company based on experience with similar processes and their use for the development of existing processes. Lewis (1998) states that tools for better use of data and information will positively influence their further use in management. Interest in strategic management of information systems and information and communication technology (ICT) has increased in the early 1990s due to the collapse of various business information systems. Until then, most businesses used data processing systems to process data and information used by central computers to process them. In most cases, data processing was off-line. Today's information systems are used at the level of data processing or information processing in most cases on-line. Only the wage module is used by most companies in off-line mode. Few companies manage information processes in the field of tactical and strategic planning, and almost no company processes in the field of collecting, distributing and sharing knowledge in the enterprise. The quality of the entire information system is determined by the capabilities and experience of senior management. If the area of information technology is underestimated for a long time, it will also affect the competitiveness of the company (Dohnal and Pour, 1999). In the long run, Voříšek (2015) is engaged in business informatics management, which also addresses the use of data and information throughout the management process. Knowledge in information systems is in most cases not stored in any database at all. The knowledge owner is not interested in, nor does it need to save their knowledge in information systems. It can be said that investments in information systems and information technologies do not guarantee a successful way of managing data, information and knowledge in the enterprise. The management of the whole department of informatics, namely information systems, information and communication technologies, is very demanding in the company. Procedures for solving the life cycle of an information system are also dealt with by Stail and Reynolds (2011). Long-term storage of large volumes of data in companies, their utilization and further processing depend on the quality and functionality of the information system, which is influenced by the quality of the entire controlling process of informatics in the company (Šilerová et al., 2017). The problem of the development of information systems, the quality of company processes and the security of data and information has long been dealt with by Polakovič et al. (2017) and Šmída (2007). 


\section{Materials and methods}

Despite the declared need for professional management of information systems and information and communication technologies, there is still a department of informatics in many enterprises and in many other enterprises this department is inappropriately included in the organizational structure. The Department of Informatics still has no more than $50 \%$ of the companies surveyed, and these departments are under the control of other departments.

The article was developed based on scientific methods - using holistic methodology, analysis, synthesis, induction and deduction. The theoretical part was created using secondary sources, studying scientific and professional articles. Based on the established hypotheses, a questionnaire was compiled, consisting of 15 questions - 12 questions were closed and 3 questions were open. A total of 152 companies from a wide spectrum of production (manufacturing, agricultural machinery, forestry, transport, car-handling, agriculture) were addressed. From the 152 companies surveyed, 42 farms were with an area of more than 1000 ha. All respondents use information systems, the information system is made up of several modules. Modules are not integrated with all respondents. Based on the results of the questionnaire survey, 78 direct enterprises were interviewed directly. Direct survey enterprises were selected according to the questionnaire survey and production specialization. All production specializations were represented in the sample of respondents for direct inquiry. Questions for direct questioning were given to respondents based on the long-term experience of the authors of the article (cooperation with practice) with the mentioned issues of information systems, management of business information systems, and information strategies. Outputs from the questionnaire survey were used to draw conclusions of the established hypotheses.

Two hypotheses will be dealt with in the presented article: H1 - in the monitored sample of enterprises there is an increasing tendency of the existing department of informatics, as a separate unit. The first hypothesis assumes an increase to $62 \%$ from 2008 to 2015 , in farms to $12 \%$. H2 - monitored respondents are used to manage information systems and information and communication technologies created information strategy. The second hypothesis assumes the information strategy developed by $58 \%$ of the respondents, in the farms in $7.5 \%$ of the respondents.

\section{Results and discussion}

The quality of the whole information system is due to many factors - the inclusion of the IT department in the organizational structure, the existence of information strategy and information systems architecture, human factor, financial resources that can be used to build an information system and to implement (or innovate) information and communication technologies. One of the main reasons for failure to implement information systems is the absence or incomplete strategic management of the entire IS/ICT area. Most authorities agree on this diagnosis - see such as Cash, McFarlan, McKeney, Donovan, Earl and Ward. Unfortunately, the "strategic management of IS / ICT" often remains at the edge of managers' interest - this is mainly due to the inappropriate inclusion of the entire IT department in the organizational structure of the company, often also by the unclear contribution of information systems and information and communication technologies. Analyzes of the use of information systems in agricultural primary production and processing industry are solved by Hennyeyova and Depes (2010).

In the period from 2008 to 2015, a selected sample of companies was monitored, including the IT department in the organizational structure, i.e. who controls information systems and information and communication technologies in the company. Historically, IT companies fell under the economic unit. This way of managing informatics was developed throughout the world (the $60 \mathrm{~s}$ and $70 \mathrm{~s}$ of the 20th century). In the economic department, the largest volumes of data were processed - accounting, warehouses, wages, property, and consequently, the management of information systems in the economic unit remained. At present, the management of the IT department is still part of the economic unit in about $16 \%$ of the companies surveyed. A very similar situation is in many countries around the world, because the way of data processing was very similar here too. However, in the sample of monitored firms, IT is increasingly being managed by IT specialists. In small companies, the owner retains the management of IT and is also responsible for it. In the big companies, the entire top management of the company is involved in the management of informatics, including the IT department manager. The survey shows 
that it is possible to combine the question whether the management of IT is directly in the management of the company, or whether it is the responsibility of the management of the IT department that is part of some other company department - in 2012, all top management was involved in managing informatics in $51.5 \%$ and later in 2013 already 52.6 $\%$. It is clear from the above-mentioned survey that in the last years it is no longer subject to IT management of the Human Resources department. In the first years of research, the Department of Informatics was part of the human resources department at $2.57 \%$ of the monitored firms. If informatics is not a separate department in the company, the quality of the whole information science in the company is negatively affected. The results of the survey are shown in Figure 1 - Management of the IT department.

The situation on farms differs significantly. On farms, $95 \%$ of information systems are used only for the processing of historical data, i.e. only for their records. Software that makes possible to use data and information to make predictions on farms is not available. This is also the way in which the field of information science is managed. The Department of Informatics is not in the monitored sample of agricultural holdings. For the management of information systems and the use of information and communication technologies, the owner, the director and the economist are responsible in $98 \%$ of the monitored enterprises. The survey carried out in a selected sample of companies did not confirm
H1 (that the IT department will be a separate unit in more than $62 \%$ of respondents and in agriculture by more than $12 \%$ of respondents). $\mathrm{H} 1$ has not been confirmed, although there is an increase in the existence of a separate IT unit, but not in such a fundamental way. In agriculture, the situation has not changed in the monitored period. Even on farms, $\mathrm{H} 1$ has not been confirmed. On farm businesses, the owner or the entire top management is still responsible for the whole computer science, without the existence of an IT department.

In monitoring the management of the IT department, it would also be worthwhile to monitor the impact of the information system on the results of the business, the competitiveness of the company, the goodwill, the social situation in the company, the cooperation with the suppliers, and the customers. Obtaining such data from companies is unfortunately very difficult because most companies are not tracking them at all, and if they track them, the data is so confidential that it's impossible to get it from companies.

The ideal proposal for inclusion of the IT department in the organizational structure of the company is shown in Figure 2. The design of this method of incorporation of the department of informatics results from the long-term research of the authors dealing with the way of information management and its influence on the development of the company.

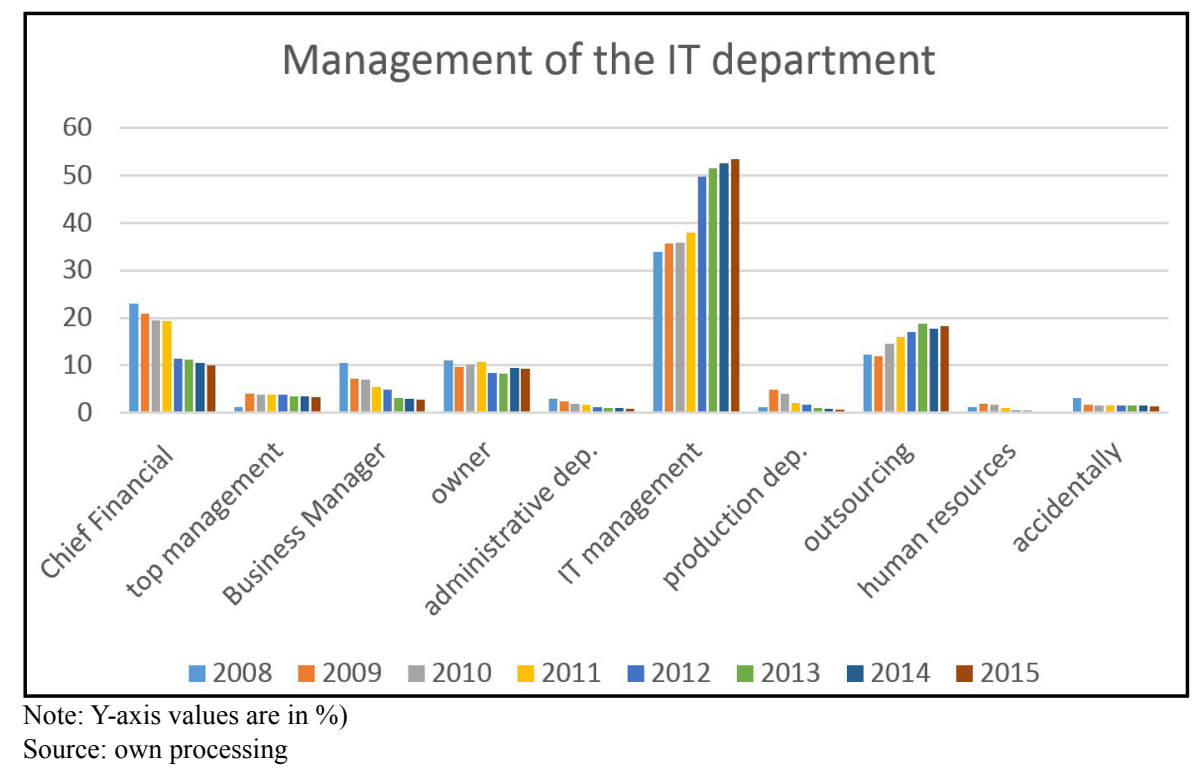

Figure 1: Management of the IT department - the proportion of IT departments. 


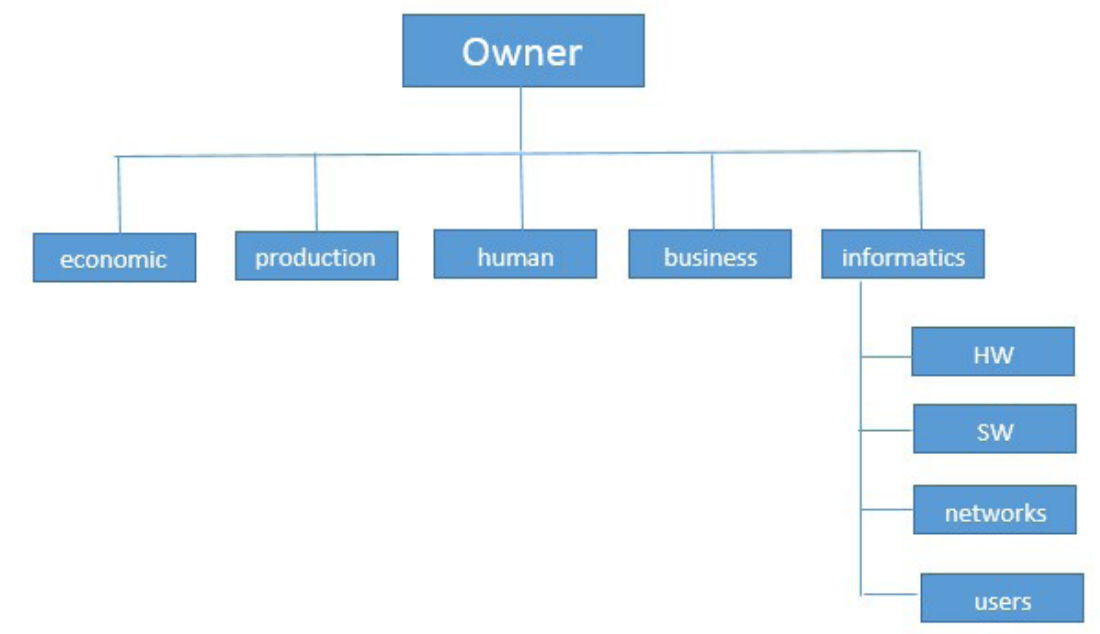

Source: own processing

Figure 2: Organizational structure of the company.

\section{Use of information strategy}

A key condition for successful implementation of a business strategy is a clear idea of what outcome ICT will be used and how information systems will be used. The information systems used in companies are relatively complex, they are made up of a large spectrum of functions, often have no user manuals, the management of the IT department is at an inadequate control level. The quality of the whole lifecycle of the information system is heavily influenced by the way of the management of the department of informatics in the company, respectively by working with data and information and their further use. The company's information strategy must always be based on corporate strategy and this is sometimes a problem because corporate strategies are often not carefully developed (Kourdi, 2009).

In order to improve the quality of enterprise information systems, the correct setting of the whole life cycle of the information system is the most valuable. One of the first steps in the life cycle of an information system is to create an information strategy. The created information strategy represents a vision of the creation and use of information systems and information and communication technologies in the company. The quality of information systems, their functionality according to the requirements of the contracting authority, is crucial for almost all processes in the company.

Currently, most large companies expect the need to apply the principles of strategy and management also in the field of informatics. With the increasing complexity of information systems and product diversity, the need for strategic management is growing and is becoming increasingly important for medium and small businesses. Information systems are characterized by heterogeneity and also by more interdependent applications that create different teams often without mutual communication. The dysfunctions and problems that occur in these systems have many negative consequences. The difficulties we encounter when determining the origin and the causes of these problems are proportional to the quality requirements of the data and information being processed. (Tchoffa et al., 2013).

Creating an information strategy is a process that helps to optimize the process of managing the information system building, implementation and operation. The aim of the information strategy is a positive change in the use of information and communication technologies - in all areas of the company where the information systems are used (Drucker, 2002). Among the well-defined objectives of the information strategy we include: defining the architecture of the future information system, defining the definitions of the effective satisfaction of user needs by the information system within the company. Strategic management of information systems must be part of strategic business management and must be tackled in close connection with the marketing strategy, manufacturing strategy, logistics and other business components that are necessary for a successful business.

The architectural design of the information system is an information strategy - defining the requirements of the information system 
to support as much as possible the business strategy of the company, the ongoing corporate processes and the performance of the individual employees. The information strategy is an important tool for investment in information systems and information and communication technologies not to be too big a bet with an uncertain outcome, with the result that companies do not become a punch in the hands of suppliers (Urban, 2004). The expected benefits and efficiency gains will not only be a dreamy fairy-tale story with no ending. The information strategy represents the enterprise's vision of using enterprise data, information, and knowledge at all levels of management.

In the same sample of enterprises as the monitoring of the existence or non-existence of the IT department, the existence of the non-existence of the information strategy was created - a document which significantly influences the overall quality of the information system (positively). The company's information strategy has been neglected for a long time and has been searching for the causes of problems with information systems in many other factors. They did not think that one of the reasons could be the lack of an information strategy, the absence of a vision.

In the monitored years 2008-2015, the existence of the information strategy has increased significantly. In 2008, the information strategy was created only in $17.9 \%$ of the monitored companies, in 2015 it was already in almost $30 \%$ of the monitored companies. In agricultural holdings, the situation is very different, with the monitored sample of farms the information strategy is only created in $5 \%$ of the monitored enterprises. These are large enterprises with an area of over 5,000 hectares. The results of the survey are shown in Figure 3 - Information strategy.

Hypothesis H2 was not confirmed too. Only $29.1 \%$ of the monitored enterprises have created an information strategy. The increase in the monitored period is $11.2 \%$, in agriculture it has grown by a whole $5 \%$, because in 2008 the information strategy was not created in any of the monitored enterprises.

It is verified that the information strategy costs from $5 \%$ to $10 \%$ of the cost of the information system. The system costs, built according to the specified strategy, then move with a $10 \%$ tolerance to the predicted - calculated price. On the other hand, the cost of an information system built without a developed information strategy is up to several times higher than the original assumptions. Therefore, many projects are not successfully completed due to the lack of information strategy. Tvrdíková (2015) also considers the possibility of using the principles of cloud computing. If the company thinks about these options, it is still far more responsible to manage all the processes involved. We will think that one of the most valuable corporate resources - data and information - is going outside the company.

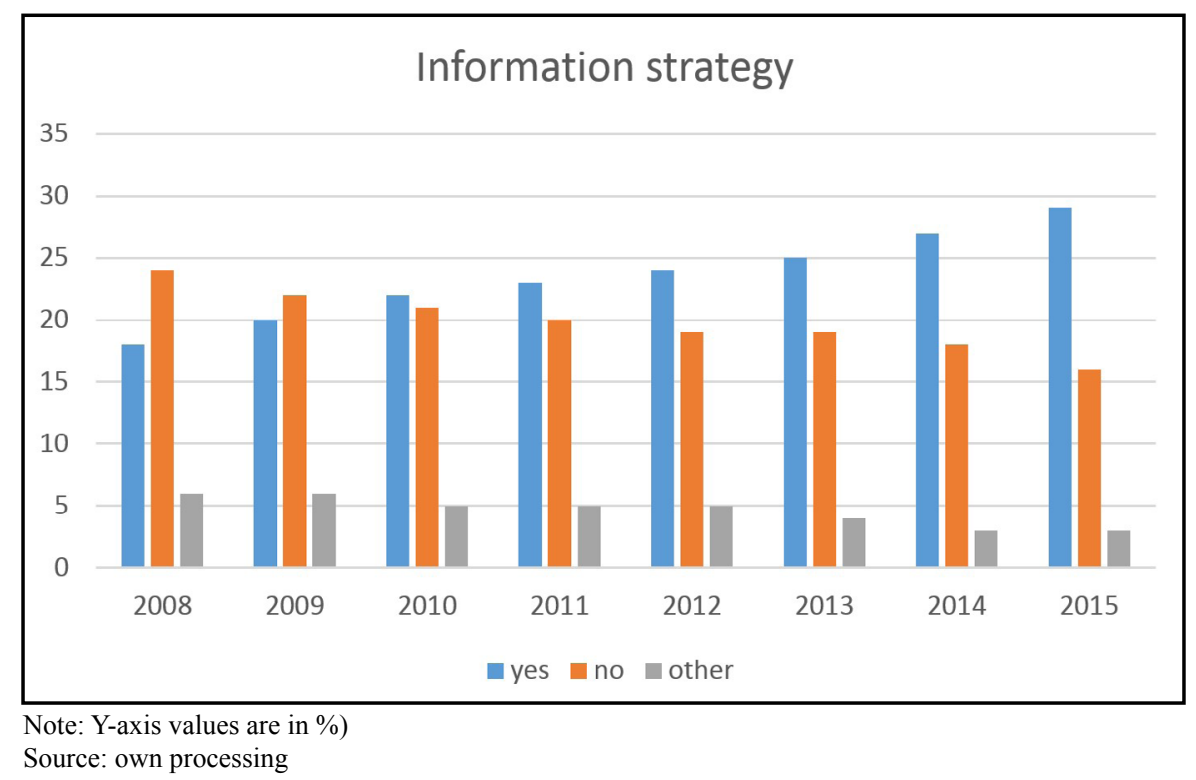

Figure 3: Existence of created information strategy. 


\section{Conclusion}

A key condition for successful implementation of a business strategy is a clear idea of what outcome ICT will be used and how information systems will be used. The information systems used in companies are relatively complex, they are made up of a large spectrum of functions, often have no user manuals, the management of the IT department is at an inadequate control level. Welch and Welch (2007) states that the management of the whole company significantly affects the correct inclusion of the IT department in the organizational structure of the company as well as the existence of an information strategy according to which the whole informatics in the company is controlled. The survey and the proposed inclusion of the IT department in the organizational structure show that the quality of the entire life cycle of the information system is heavily influenced by the management of the IT department in the company, by working with data and information and their further utilization and, of course, by the existence of an information strategy.

Corresponding author:

Ing. Edita Šilerová, Ph.D.

Department of Information Technologies, Faculty of Economics and Management, Czech University of Life Sciences Prague, Kamýcká 129, 16500 Praha 6-Suchdol

E-mail: silerova@pef.czu.cz

\section{References}

[1] Dohnal, J. and Pour, J. (1999) "Řizení podniku a ř́zení IS/IT v informační společnosti" (in Czech), Prague: University of Economics, 118 p. ISBN 80-7079-023-7.

[2] Drucker, P. F. (2002) “To nejdůležitějši z Druckera vjednom svazku" (in Czech), Prague: Management Press, 304 p. ISBN 80-7261-066-X.

[3] Hennyeyova, K. and Depes, P. (2010) "Analysis of the exploitation of information and communication technologies in the agri-food sector companies", Agricultural Economics, Vol. 56, No. 9, pp. 403 - 408. ISSN 0139-570X.

[4] Kourdi, J. (2011) "Podniková strategie" (in Czech), ComputerPress, a.s., Prague, 300 p. ISBN 978-80-251-2725-4.

[5] Lewis, T. (1998) "Evolution of farm management information systems", Computers and Electronics in Agriculture, Vol. 19, pp. 233-248. ISSN 0168-1699. DOI 10.1016/S0168-1699(97)00040-9.

[6] Urban, J. (2004) "(Tvorba a rozvoj organizačních systému, in Czech)”, Management Press, Praha. 2004. p. 161. ISBN 80-7261-405-4.

[7] Polakovič, P., Hallová, M., Šilerová, E., Hanová, M. (2017) "The Safety of Information and Communication Technologies in the Context of Existing Agriculture Companies", International conference Agrarian Perspectives XXVI. - Competitivenes of European, pp. 293 - 298. ISBN 978-80-213-2787-0.

[8] Stail, R. and Reynolds, G. (2011) "Fundamentals of Information Systems", Course Technology, Boston, 458 p. ISBN 978-0840062185. 
[9] Šilerová, E., Hennyeyová, K., Vaněk, J., Stočes, M., Pechrová, M. and Michálek, R. (2017) “Inteligent tools for data and information evaluation", International conference Agrarian Perspectives XXVI. - Competitivenes of European Agriculture, pp. 396 - 402. ISBN 978-80-213-2787-0.

[10] Šmída, F. (2007) "Zavádění a rozvoj procesního řizení ve firmě” (in Czech), GradaPublishing a.s. Prague. 300 p. ISBN 978-80-247-1679-4.

[11] Tchoffa, D., Duta, L. and El Mhamedi, A. (2013) "Decision Analysis in Management of Information Systems Incidents", Studies in informatics and control, Vol. 22, No. 2, pp. 123-132. ISSN 1220-1766.

[12] Tvrdíková, M. (2016) "Increasing the Business Potencial of Companies by Ensuring Continuity of the Development of their Information Systems by Current Information Technologies", Journal of Business Economics and Management, Vol. 17, No. 3, pp. 475-489. ISSN 1611-1699. DOI 10.3846/16111699.2013.839475.

[13] Voříšek, J. (2015) "Principy a modely řizení podnikové informatiky" (in Czech), Prague, Oeconomica, 446 p. ISBN 978-80-245-2086-5.

[14] Welch, J. and Welch, S. (2007) "Komu podřídit útvar IT?" (in Czech), Moderní řizení, No. 2, pp. 45 - 46. [Online]. Available: http://modernirizeni.ihned.cz/c1-20362640-komu-podridit-utvar-it [Accessed: 25 Sept 2017]. ISSN 00268720. 